\title{
Research on Measurement of Service Capability of Logistics Enterprise
}

\author{
Xiao-Juan Bai, Miao Su \\ Beijing Wuzi University, Beijing, China \\ E-mail: baixiaojuan@sina.com, 864134025@qq.com
}

\begin{abstract}
The paper illustrated the key point in qualitative method. One of the three types of major logistics enterprises is selected as the main research object, and Service capability measurement system is established from 6 perspectives. By taking reference to the core idea of the correlation matrix method, the paper conduct measure research to its research object using quantifiable measure and get a comprehensive measure value. Enterprise in this field can improve its logistic service ability and conduct strategic analysis, strategic adjustment according to the research.
\end{abstract}

Keywords-service capacity, Measure index, Correlation matrix method

\section{INTRODUCTION}

\section{A. Research background and its importance.}

In Recent years, the economy was facing a downward trend in European and American economies, and economy in China has entered a new normal environment. Logistics industry continues to meet the challenges and opportunities. In generally, Domestic logistics industry is stable, and continues to make all kinds of breakthroughs. However, in the meantime, European and American logistics enterprise find it hard to meet its business target in their own market. Therefore, they want to further tap logistic market in China, which will definitely make the market competition more fiercely. So for logistic enterprise, improving its logistic service is becoming more and more important and urgent. In China, high logistics costs and low level of logistics services situation must be improved. Numerous studies show that: Chinese Logistics companies rarely focus on internal service capacity deep causal relationship, they only see the lack of an external surface of logistics capability, but can not have in-depth discussion of the internal reasons, and they can not realize the importance of the overall capacity measurement, all of the problems lead a large number of local companies died. Thus, through research and analysis of meaning of the logistics service capability, and classified the summed up capabilities, combined with their own internal and external environment, to optimize the ability and further the company's own strong force is very important.

\section{II.Logistics Service Capability Measurement System}

\section{B. The definition of Logistics service capabilities.}

From the perspective of logistics enterprises, after in-depth study of enterprise resource management, service management, infrastructure cost management, staff management, and using theory from customer management. In the paper, logistic service capabilities are defined as: The ability to meet the demand of its customer and to create value to its customer and to win customer identity.

The establishment of logistics service capacity measurement system. Six major capabilities are established, which is specifically divided 20 capabilities as the following chart shows:

TABLE I. EVALUATION INDEX SYSTEM OF LOGISTICS SERVICE CAPABILITY

\begin{tabular}{|c|c|c|}
\hline \multirow{10}{*}{$\begin{array}{c}\text { Evaluation index } \\
\text { system of logistics } \\
\text { service capability } \\
\text { X }\end{array}$} & \multirow{4}{*}{$\begin{array}{l}\text { Warehousing and logistics } \\
\qquad X_{1}\end{array}$} & Inventory management $X_{11}$ \\
\hline & & cross docking operation $X_{12}$ \\
\hline & & Distribution efficiency $X_{13}$ \\
\hline & & Circulating Processing $X_{14}$ \\
\hline & \multirow{3}{*}{ Resource equipment $X_{2}$} & Staff professional skill level $X_{21}$ \\
\hline & & Supply chain integration $X_{22}$ \\
\hline & & Intelligent device adaptation rate $X_{23}$ \\
\hline & \multirow{3}{*}{ information processing $X_{3}$} & Information system $X_{31}$ \\
\hline & & Order processing efficiency $X_{32}$ \\
\hline & & information management $X_{33}$ \\
\hline
\end{tabular}


TABLE I. EVALUATION INDEX SYSTEM OF LOGISTICS SERVICE CAPABILITY(CONTINUED)

\begin{tabular}{|c|c|c|}
\hline \multirow{10}{*}{$\begin{array}{l}\text { Evaluation index } \\
\text { system of } \\
\text { logistics service } \\
\text { capability X }\end{array}$} & \multirow{4}{*}{$\begin{array}{r}\text { Customer } \\
\text { service } X_{4}\end{array}$} & Customer service quality $X_{41}$ \\
\hline & & Humanized service $X_{42}$ \\
\hline & & Complaint handling prescription $X_{43}$ \\
\hline & & Service recovery capability $X_{44}$ \\
\hline & \multirow{3}{*}{ Innovative learning $X_{5}$} & learning ability $X_{51}$ \\
\hline & & Continuous improvement ability $X_{52}$ \\
\hline & & Service innovation capability $X_{53}$ \\
\hline & \multirow{3}{*}{$\begin{array}{c}\text { Enterprise performance } \\
\qquad X_{6}\end{array}$} & Profitability $X_{61}$ \\
\hline & & Customer satisfaction level $X_{62}$ \\
\hline & & Overall competitive position $X_{63}$ \\
\hline
\end{tabular}

\section{Correlation matrix method.}

One of the most effective and simple solutions to complex problems is matrix model, as you can see from its name. Correlation matrix method is to use an alternative form of a matrix-like system, every system in the relevant measure indicators, and the use of mathematical modeling thought the quantitative indicators, then the idea of using matrix computation measured results.

\section{PRACTICAL EXAMPLES OF SERVICE \\ CAPABILITY MEASUREMENT OF INTEGRATED LOGISTICS ENTERPRISE}

\section{A. Selecting measurement elements.}

In the chapter, we take an example of integrated logistic

TABLE II. Selected measurement elements enterprise. If we use comparison method according to 20 indexes that has been originally determine, it it very difficult to operate because the work is so much, so we selected 8 from 20 elements according to the practical condition. In order to obtain reliable scientific data, we have listened advice from a wide range of enterprise logistics experts, senior practitioners and professors in logistics teaching, and select the most recognized eight indicators which are showed as following:

\begin{tabular}{|c|c|}
\hline index & index \\
\hline Inventory management $X_{11}$ & Customer service quality $X_{41}$ \\
\hline cross docking operation $X_{12}$ & Service recovery capability $X_{44}$ \\
\hline Intelligent device adaptation rate $X_{23}$ & Continuous improvement ability $X_{52}$ \\
\hline Order processing efficiency $X_{32}$ & Overall competitive position $X_{63}$ \\
\hline
\end{tabular}




\section{B. Determine Index weight.}

Comparing the selected 8 elements .In this paper, we take expert opinion consensus method, experts agree will eventually come to a score as the final score. The ratio of the total score and the number of comparisons was the right evaluation indexes, which can be showed as the following chart:

Calculation process: the cumulative score / overall scores $(28)=$ weight
Comparing various elements each by each:

If the former is more important, the former get 1 point, 0 points for the later;

If the later is more important, the former get 0 point, 1 points for the later;

Summing each element of the final scores, and calculate how many percentage each element is accounted for overall weight, the result of which is the wanted weight.

TABLE III. SCORE OF PAIRWISE COMPARISON

\begin{tabular}{|c|c|c|c|c|c|c|c|c|c|c|c|c|c|c|c|c|c|c|c|c|c|c|c|c|c|c|c|c|}
\hline \multirow[b]{2}{*}{$\begin{array}{c}\text { Inde } \\
x\end{array}$} & \multicolumn{26}{|c|}{ Comparison times } & \multirow[b]{2}{*}{$\begin{array}{c}\text { Cumula } \\
\text { tive } \\
\text { score }\end{array}$} & \multirow[b]{2}{*}{ weight } \\
\hline & 12 & 3 & 4 & \begin{tabular}{l|l}
5 & 6
\end{tabular} & 7 & 8 & 9 & 10 & 11 & 12 & 13 & 14 & 15 & 16 & 17 & 18 & 19 & 20 & 21 & 22 & 23 & 24 & 25 & 26 & 27 & 28 & & \\
\hline$\left|\begin{array}{c}\text { Inve } \\
\text { ntory } \\
\text { mana } \\
\text { geme } \\
\text { nt } \\
X_{11}\end{array}\right| 1$ & & & \begin{tabular}{l|l}
1 & 1
\end{tabular} & $1 \mid 1$ & & & & & & & & & & & & & & & & & & & & & & & 5 & 0.18 \\
\hline $\mid \begin{array}{c}\text { cross } \\
\text { dock } \\
\text { ing } \\
\text { oper }\end{array}$ & & & & & & 1 & 1 & & & 1 & & & & & & & & & & & & & & & & & 3 & 0.11 \\
\hline \begin{tabular}{|c|} 
Cont \\
inuo \\
us \\
impr \\
ove \\
ment \\
abilit \\
y \\
$X_{52}$
\end{tabular} & & & & & & & & & & & & & & & & & & & & & & & & & & & 0 & 0 \\
\hline \begin{tabular}{|c|} 
Intell \\
igent \\
devic \\
e \\
adapt \\
ation \\
rate \\
$X_{23}$
\end{tabular} & & 1 & & & & & 1 & & & & & 1 & & & & 1 & & & & & & & & & & & 4 & 0.14 \\
\hline
\end{tabular}


TABLE III. SCORE OF PAIRWISE COMPARISON(CONTINUED)

\begin{tabular}{|c|c|c|c|c|c|c|c|c|c|c|c|c|c|c|c|}
\hline $\begin{array}{c}\text { Orde } \\
\text { r } \\
\text { proc } \\
\text { essin } \\
\text { g } \\
\text { effici } \\
\text { ency } \\
X_{32}\end{array}$ \\
\hline $\begin{array}{c}\text { Cust } \\
\text { omer } \\
\text { servi } \\
\text { ce } \\
\text { quali } \\
\text { ty } \\
X_{41}\end{array}$ \\
\hline $\begin{array}{c}\text { Servi } \\
\text { ce } \\
\text { reco } \\
\text { very } \\
\text { capa } \\
\text { bility } \\
X_{44}\end{array}$
\end{tabular}

After obtaining the degree of importance, we need to rate various elements of different enterprises. We selected 5 levels of evaluation index respectively named excellent,

good, fair, poor, very poor as a business dimension, which are showed as following TABLE IV:

\section{TABLE IV. SCORE STANDARD REFERENCE}

\begin{tabular}{|l|c|c|c|c|c|}
\hline Ratings & Excellent & Good & Fair & Poor & Very poor \\
\hline Score & 5 & 4 & 3 & 2 & 1 \\
\hline
\end{tabular}

Expert scoring, the paper selected six well-known domestic and foreign enterprises to measurement its logistic service capabilities, which are named: A, B, C, D, E, F. After the logistics scholars, professors reach consensus, each element are set points. On the basis of expert opinion the views of more senior people, the results of each enterprise score are determined as following: 
TABLE V. EXPERT SCORING

\begin{tabular}{|c|c|c|c|c|c|c|c|c|}
\hline & $\begin{array}{c}\text { Inventory } \\
\text { management } \\
X_{11}\end{array}$ & $\begin{array}{c}\text { cross } \\
\text { docking } \\
\text { operation } \\
X_{12}\end{array}$ & $\begin{array}{c}\text { Continuous } \\
\text { improvement } \\
\text { ability } X_{52}\end{array}$ & $\begin{array}{c}\text { Intelligent } \\
\text { device } \\
\text { adaptation } \\
\text { rate } X_{23}\end{array}$ & $\begin{array}{c}\text { Order } \\
\text { processing } \\
\text { efficiency } \\
X_{32}\end{array}$ & $\begin{array}{c}\text { Customer service } \\
\text { quality } X_{41}\end{array}$ & $\begin{array}{c}\text { Service recovery } \\
\text { capability } X_{44}\end{array}$ & $\begin{array}{c}\text { Overall } \\
\text { competitive } \\
\text { position }\end{array}$ \\
\cline { 2 - 9 }$X_{63}$
\end{tabular}

\section{A. Result.}

The correlation matrix table can be drawn from table 4 and table 6.The comprehensive measurement results of the program are as follows:

$$
\begin{aligned}
& V_{A}=0.18 * 4+0.11 * 4+0 * 3+0.14 * 4+2 * 0.14+1 * 0.11+0.07 * 3+0.25 * 3=3.07 \\
& V_{B}=0.18 * 5+0.11 * 3+0 * 4+0.14 * 2+0.14 * 2+0.11 * 1+0.07 * 3+0.25 * 4=4.18 \\
& V_{C}=0.18 * 3+0.11 * 3+0 * 3+0.14 * 4+0.14 * 4+0.11 * 5+0.07 * 4+0.25 * 2=2.96 \\
& V_{D}=0.18 * 4+0.11 * 5+0 * 3+0.14 * 3+0.14 * 4+0.11 * 3+0.07 * 2+0.25 * 3=4.01 \\
& V_{E}=0.18 * 4+0.11 * 3+0 * 3+0.14 * 4+0.14 * 4+0.11 * 5+0.07 * 5+0.25 * 3=3.82 \\
& V_{F}=0.18 * 3+0.11 * 3+0 * 2+0.14 * 2+0.14 * 3+0.11 * 4+0.07 * 3+0.25 * 2=2.72
\end{aligned}
$$

According to the final score we can know: $V_{B}>V_{D}>V_{E}>$ $V_{A}>V_{C}>V_{F}$, which shows clearly that enterprise $\mathrm{B}$ are the best in terms of logistic service capability.

\section{CONCLUSION}

Based on the study of the existing literature, the authors put forward the definition of the logistics service capability and the ability to solve the logistics service measurement of approach. At the same time, the author use relational matrix analysis to conduct logistics service capacity measurement, in such a direct way to illustrate the originally difficult and abstract logistic service capabilities. With the increasing competition in the market, companies must have certain level of logistics service capabilities to meet the needs of the market. Logistics management is so fun that it attracts so many experts in this field to research it. Logistics Company should put the improvement of its competence in the first place to survive in the increasing fierce market. In the future, we will explore deeper about the more accurate measure, and use more in-depth mathematical model to resolve logistics indicators, trying to contribute for the logistic industry in China by the common efforts of my research and related enterprises.

\section{REFERENCES}

[1] Donald j. Bauer sox waiting, Guo-Long Lin et al., In the process of logistics management, supply chain integration, Beijing: mechanical industry press, 1999.

[2] Chun-Ying Zhang, Xue-Fei Li, The third party logistics enterprise logistics service ability empirical research Changchun University, Changchun University of technology, 2014.

[3] Shao-Rong Li, Qi-Lan Zhao, "Double base points based on entropy weight of logistics service capability evaluation", journal of Beijing Jiao Tong University (social science edition), 2010.

[4] Shan Li, Hao Jin, "Shipping logistics of our country enterprise logistics service capability evaluation", the empirical analysis of Jilin University's finance and economics, 2014.

[5] Yan-Wen Yang, Jie Wang, Automobile supplier's logistics service capability evaluation system establishment, Shanghai gm Wuling automobile co., LTD., 2015. 